\title{
Approaches of family physicians working in primary care regarding palliative care
}

Birinci basamakta çalışan aile hekimlerinin palyatif bakımla ilgili yaklaşımları

\author{
iDUfuk Unlu ${ }^{\mathrm{a}}$, iDOznur Sahin ${ }^{\mathrm{a}}$, iDNagihan Yildiz Celtik ${ }^{\mathrm{a}}$ \\ a Department of Family Medicine, Faculty of Medicine, Tokat Gaziosmanpasa University, Tokat, Turkey
}

\begin{abstract}
Introduction: Determining the awareness of family physicians working in primary care about palliative care, to determine their attitudes and behaviors towards patients and their relatives, and their approaches are aimed in this study.

Methods: The universe of the cross-sectional and descriptive study consists of 194 family physicians in Tokat in January 2020 . However 23 physicians who refuse to participate and 15 physicians who could not reached in detected dates were excluded from the study. 156 physicians were applied prepared questionnaire. The necessary permissions were obtained from the Provincial Health Directorate and the clinical research ethics committee. The data were evaluated with IBM Statistics 20.0 SPSS statistical software. Chi-square test was used to test the differences, and $\mathrm{p}<0.05$ was accepted statistically significant.

Results: Regarding participants 98 (62,8\%)were male, 58 (37,2\%) female, mean age 40,5 $\pm 9,8$ and mean working years 15,8. 6.4\% (n: 10) of the participants were family medicine specialists and $93.6 \%$ (n: 146) general practitioners. The proportion of respondents who state the correct answer as 'palliative care deals with lifethreatening diseases' was $60.3 \%$. The proportion of those who helped palliative care patients about nutrition was $29.5 \%$ (n: 46 ) and 60 physicians supported for psychiatric problems (38.5\%). $51.3 \%$ of the physicians prescribed opioid group drugs. The rate of those who want to follow patients in the family health center as integrated with the palliative care units $20.5 \%$, and this rate was found to be statistically significantly higher in female physicians (p: 0.03 ). $11.5 \%$ of the physicians received palliative care training, while $61.5 \%$ stated that they wanted to receive regular training in this regard.26.9\% of participants want to specialize in palliative care. $74.3 \%$ of physicians think that palliative care practices should not be included into performance system in the family medicine practices.

Conclusions: In the current system, it was found that family physicians did not have sufficient training and equipment related to palliative care. In line with the increasing need for palliative care in primary care, some up-to-date arrangements and in-service trainings should be brought to the agenda.
\end{abstract}

Keywords: Family practice, palliative care, pain, opioid analgesics, palliative care training

\section{$\ddot{O} \mathbf{z}$}

Giriş: Bu çalışmada, birinci basamakta çalışan aile hekimlerinin palyatif bakım konusundaki farkındalıklarını saptamak, hasta ve yakınlarına karşı tutum ve davranışlarını belirlemek, yaklaşımlarını saptamak amaçlanmıştır.

Yöntem: Kesitsel ve tanımlayıcı nitelikteki araştırmanın evrenini 2020 yılı Ocak ayında Tokat’ta 194 adet aile hekimi oluşturmaktadır. Çalışmaya katılmayı kabul etmeyen 23 kişi ve belirlenen sürede ulaşılamayan 15 kişi çalışma grubunun dışında bırakılmıştır. İlgili 156 hekime ulaşılmış, hazırlanan anket formu uygulanmıştır. Araştırma için İl Sağlık Müdürlüğ̈̈’nden ve klinik araştırmalar etik kurulundan gerekli izinler alınmıştır. Veriler IBM Statistics 20.0 SPSS istatistik paket programı ile değerlendirilmiştir. Farklılıkların test edilmesinde Ki-kare testi kullanılmış, $\mathrm{p}<0,05$ istatistiksel açıdan anlamlı kabul edilmiş̧ir.

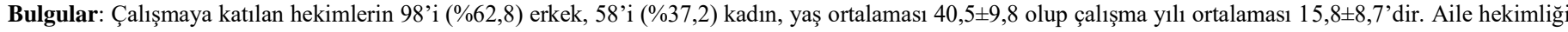
yapanların \%6,4'ü (n:10) Aile Hekimliği Uzmanları, \%93,6'sı (n:146) pratisyen hekimlerden oluşmaktadır. Palyatif bakım hayatı tehdit eden hastalıklar ile ilgilenir doğru cevabını belirten katılımcıların oranı \%60,3'tür.Palyatif bakım hastasına beslenme konusunda yardımcı olanların oranı \%29,5(n:46) olup, psikiyatrik problemleri için destek olan 60 kişidir $(\% 38,5)$. Hekimlerin \%51,3’ü palyatif bakım hastalarına opioid grubu ilaç reçete etmiştir. Aile sağlığı merkezinde palyatif bakım ünitesi ile entegre şekilde hasta takip etmek isteyenlerin oranı \%20,5 olup kadın hekimlerde bu oran erkeklere göre istatistiksel açıdan anlamlı derecede yüksek bulunmuştur(p:0,03). Hekimlerin \%11,5'i palyatif bakım eğitimi almış, \%61,5'i ise bu konuda düzenli bir eğitim almak istediğini belirtmiştir. Palyatif bakım alanında uzmanlaşmak isteyenlerin oranı \%26,9'dur. Hekimlerin $\% 74,3$ 'ü palyatif bakım uygulamalarının aile hekimliği sisteminde performansa dahil edilmemesi gerektiğini düşünmektedir.

Sonuç: Mevcut sistemde aile hekimlerinin palyatif bakım ile ilgili yeterli eğitime ve donanıma sahip olmadıkları saptanmışıı. Birinci basamakta giderek artan palyatif bakım ihtiyacına paralel olarak bu alanda bir takım güncel düzenlemeler yapılması ve hizmet içi eğitimlerin gündeme getirilmesi gereklidir.

Anahtar Kelimeler: Aile hekimliği, palyatif bakım, ağrı, opioid analjezikler, palyatif bakım eğitimi

\begin{tabular}{|c|c|c|c|c|}
\hline Received & Accepted & Published Online & Corresponding Author & E-mail \\
\hline August 9, 2021 & December 31, 2021 & March 17, 2022 & Ufuk Unlu, M.D. & drufukunlu@ @mail.com \\
\hline Correspondence & Dr. Ufuk Ünlü, Alt1yüzeler mah. Çeşme sok. No.14 Daire:5 Merkez / Tokat-Turkey \\
\hline doi & https://doi.org/10.22391/fppc.980400 \\
\hline
\end{tabular}




\section{Introduction}

"Palliative Care" is defined by the World Health Organization (WHO) as "an approach that aims to meet the physical, psychosocial and spiritual needs of patients and their relatives, who face life-threatening diseases, by detecting pain and other problems in the early period and by a detailed evaluation in order to increase the quality of life" [1]. Since it is essential to evaluate the patient in all aspects and to offer solutions in palliative care, a well-organized multidisciplinary team is required. A good organization of the palliative team is possible if the physicians working in this field are well trained and equipped with enough experience. It is extremely important in patient care and follow-up that family physicians, who are easily accessible, must have sufficient knowledge and skills in palliative care [2].

In parallel with the efforts of the Palya-Türk project in our country in 2010, the palliative care directive was available in 2014 and included in the payment scope by the social security institution [3]. In the Palya-Türk project, palliative care centers were organized as first, second and third level. First level palliative care service is planned as service delivery by family physicians, home care team, non-governmental organizations and local governments. It is aimed to follow the limited medical interventions and routine controls of the patients such as symptom management, drug administration, wound care at home and to refer the patients to second or third level centers if needed [4]. In line with these plans, as of 2019, palliative care services are provided in 81 provinces in our country, in 403 health facilities, with a bed capacity of 5426 [5]. At the point reached today, although the number of institutions and beds providing services in the second and third level is increasing rapidly, the primary level is still only with home care services, and it is difficult to respond to the increasing need. The need for a palliative care training program for family physicians, who frequently encounter patients in need of palliative care, is gaining importance day by day. In this way, an increase in the quality of service provided to patients can be achieved. Comprehensive studies on the subject are needed. In this study, it was aimed to determine the awareness of family physicians working in primary care about palliative care, to determine their attitudes and behaviors towards patients and their relatives, and to determine their approaches.

\section{Methods}

The population of the cross-sectional and descriptive study. The sample of study consists of 194 family physicians working under the Tokat Provincial Health Directorate Family Medicine unit in January 2020. It is aimed to reach the entire population without selecting a sample. 23 people from the target group did not accept to participate in the study and 15 people were excluded from the study group because they could not be reached within the specified time. Between 15-30 January 2020, 156 physicians were reached, and the questionnaire with 27 multiple choice questions prepared by the researchers in company with the relevant literature was applied by face-to-face interview method. Necessary permission was obtained from the Tokat Provincial Health Directorate. Ethics committee approval was received from the Clinical Research Ethics Committee of Tokat Gaziosmanpasa University on 09.01.2020 and was numbered 20-KAEK-010. The data were evaluated with the IBM Statistics 20.0 SPSS (SPSS Inc., Chicago, IL, USA,) statistical package program, and the sociodemographic characteristics, descriptive characteristics and awareness of the participants on palliative care were compared. Descriptive data were shown with number (n), percent (\%) and mean standard deviations, Chi-square test was used to test the differences, $\mathrm{p}<0.05$ was considered statistically significant.

\section{Results}

Of the physicians participating in the study, 98 (62.82\%) were male and $58(37.17 \%)$ were female. The mean age was $40.5 \pm 9.8$ years and the average working year was $15.8 \pm 8.7$. Of those who practice family medicine, $6.41 \%$ (n:10) are Family Medicine Specialists, and 93.58\% (n:146) are general practitioners. $41 \%$ (n: 64) of physicians have palliative care patients registered in their population. To the question of whether there is a palliative care center in Tokat, $84(53.84 \%)$ of the participants answered yes, $4(2.56 \%)$ answered no and $68(43.58 \%)$ answered as I do not know.

\section{Nutrition support}

The rate of those who helped on the nutrition to palliative care patients is $29.48 \%$ (n:46). $14.10 \%$ (n:22) participants prescribed enteral nutritional products and $3.84 \%$ (n:6) participants provided training for nutrition. $1.28 \%$ (n:2) physicians carried out maintenance of feeding catheter and $1.28 \%$ (n:2) physicians referred upper center in order to be applied feeding catheter. The rate of those who could not help their patients with nutrition was $70.51 \%$ (n: 110). 8.97\% (n:14) of the participants stated that they did not have enough information on this subject, $1.28 \%$ (n:2) participants stated that this job was not in their responsibility, and $3.84 \%$ (n:6) physicians thought that it was not right to provide nutritional support to palliative care patients.

\section{Opioid drugs}

51.28\% of physicians prescribed opioid drugs to palliative care patients. The rate of those who did not prescribe was $48.71 \%, 3.84 \%$ (n:6) physicians stated that they did not have enough knowledge about opioids. On the other hand, $6.41 \%$ (n:10) participants stated that it was not their responsibility and $1.28 \%$ (n:2) participants did not prescribe because these drugs could be addictive. On the other hand 60 participants (38.46\%) helped palliative care patients for their psychiatric problems. The rate of those who cannot help is $61.53 \%$, and $10.42 \%$ of them think that this job is not in their area of responsibility. (Table 1)

Table 1. Participants' experiences with palliative care patients*

\begin{tabular}{|c|c|c|c|}
\hline Experiences & Nutritional Support & Opioid Prescribing & Psychiatric Support \\
\hline Yes & $29.48 \%(\mathrm{n}: 46)$ & $51.28 \%(\mathrm{n}: 80)$ & $38.46 \%(\mathrm{n}: 60)$ \\
\hline No & $70.51 \%(\mathrm{n}: 110)$ & $48.71 \%(\mathrm{n}: 76)$ & $61.53 \%(\mathrm{n}: 96)$ \\
\hline
\end{tabular}

*The minority of the participants provided nutritional and psychological support to palliative care patients. On the other hand, just half of the participants prescribed opioids to the patients. 


\section{Follow up palliative care patients}

Regarding the participants the rate of those who think that supportive treatment should be continued in terminal stage palliative care patients is $48.7 \%$. The rate of those who wanted to follow up patients in the family health center as integrated with the palliative care unit was $20.51 \%$, and this rate was found to be statistically significantly higher in female physicians than in males $(\mathrm{p}=0.03)$. If appropriate opportunities are provided, the rate of physicians who find it right to meet their health needs by making home visits is $41.66 \% .67 .94 \%$ of the participants do not consider intravenous drug treatment appropriate at home under the supervision of a physician or health personnel, and $62.82 \%$ in a family health center. Family medicine specialists' approval of intravenous drug administration at home was found to be significantly different from that of general practitioners $(\mathrm{p}=0.001)$. The rate of those who want to provide education and support to patients' relatives about patient care and the problems they may encounter is $56.41 \%$ (Table 2 ).

Table 2. The opinions of the participants about the palliative care in family medicine*

\begin{tabular}{lr}
\hline \multicolumn{1}{c}{ Subjects } & Rate of Supporters \\
\hline Being continued to supportive treatment in terminal stage palliative care patients & $48.71 \%$ \\
$(\mathrm{n}: 76)$ \\
Volunteering following up patients in the family health center as integrated with the palliative care unit & $20.51 \%(\mathrm{n}: 32)$ \\
Volunteering education on this subject & $61.53 \% \quad(\mathrm{n}: 96)$ \\
\hline * The participants' desire to receive training on the subject was seen. Due to the lack of information, there is less support for palliative care practices.
\end{tabular}

\section{Palliative care training}

Only $11.53 \%$ (n: 18) of the physicians received palliative care training, and 61.53\% (n:96) stated that they wanted to receive regular training on this subject. The rate of those who want to specialize in the field of palliative care is $26.92 \%$ (n:42). There was no statistically significant difference between family medicine specialists and general practitioners in the desire to specialize $(\mathrm{p}=0.500)$.

\section{Discussion}

Approximately 9 out of 10 physicians who practice family medicine are faced with palliative care patients. Half of the physicians have palliative care patients. More than half of the participants in their routine study programs prescribed opioids to this patient group, and about one-third assisted with nutrition. Although the encounter rates are high, just one out of every five physicians stated that they want to follow a palliative care patient. Most of the participants did not find it appropriate to administer intravenous medication at home or in a family health center. $88.46 \%$ of the physicians did not receive palliative care training, and $61.53 \%$ of all participants stated that they wanted to receive training on this subject regularly.

According to the WHO, palliative care is a service that should be given to all patients who encounter life-threatening diseases [2]. In the study conducted by Miniksar et al., $42.5 \%$ of the participants, consisting of healthcare professionals, preferred palliative care to improve the quality of life of patients and their relatives who have life-threatening diseases, $30 \%$ to improve the quality of life of the end-stage patients, and $16.3 \%$ to increase the quality of life of patients with mental and religious and providing physical support, $11.3 \%$ defined it as end-of-life care [6]. In a similar study conducted in Bitlis province, $65.9 \%$ of health personnel stated palliative care as end-stage support care, $10.7 \%$ as cancer treatment, and $10.7 \%$ as pain management [7]. In our study, target patients group of palliative care was defined as the patients in the rehabilitation program by $39.7 \%$ of the participants, while $60.3 \%$ of physicians defined patients who have life-threatening diseases. As it is understood from the studies, it is clearly seen that the family physicians responsible for providing this service do not have sufficient information about the content of the palliative care service and the patient population.

Palliative care centers in Germany provide services in cooperation with the patient's family doctor, home care services, hospice and similar organizations. Palliative care in-service trainings are given to health personnel working in these centers at regular intervals, and palliative care and treatment are also included in the pricing [8]. In a study conducted by Turgay, 86.2\% of health workers stated that they did not receive training on palliative care [9]. Miniksar et al. determined that $77.6 \%$ of the nurses and all of the doctors did not receive training on this subject, and that $71.6 \%$ of the nurses and $100 \%$ of the physicians needed training [6]. In the study conducted by Tanriverdi et al., by reaching 1734 physicians via e-mail and social media, $84 \%$ of the participants stated that they did not receive palliative care training [9]. In our study, similar to the literature, $88.46 \%$ of the physicians stated that they did not receive any training on this subject.

Miniksar et al. revealed in their study that most of the physicians had a negative attitude towards palliative care. Despite the negative perspectives, $84 \%$ of the participants stated that there should be palliative care courses in the graduate program [6]. In our study, 20.5\% of the physicians stated that they could follow the palliative care patients, $42.3 \%$ made a home visit, and 56.4\% gave training to the relatives of the patients. Although the rate of those who want to work actively in the field is low, most of the participants (61.5\%) said that they want to receive training on this subject. In their study, Miniksar et al. determined that physicians needed more effective training on palliative care [6]. Pelayo et al. have shown that online palliative care training is effective in increasing the knowledge of primary care physicians [10].

According to WHO data, palliative care education is provided in all medical faculties in only 13 countries in the European region [11]. Although the need for palliative care is increasing day by day, the necessary subjects in the field of palliative care in auxiliary health personnel training and medical education have not yet been included in the relevant curricula [12]. Therefore, the number of trained personnel in this field is extremely insufficient. For this reason, training should be given to health workers at regular intervals and regularly. Trainings should include informing healthcare professionals about the services provided in the last period of life, making joint decisions with patients and their relatives, coping with increasingly difficult cases, solving ethical problems that arise during clinical practices, and compliance with teamwork. This training should be 
organized to include all team members working in palliative care, such as dietitians, psychologists, social workers and clergy. In addition, individuals working in this field should be supported psychosocially in order to prevent burnout syndrome [11].

In Family Medicine practice, a holistic, comprehensive and coordinated service is provided to the patient with a biopsychosocial approach, without discrimination of age, gender and so on. Diseases of the patient are managed and followed up without distinction as acute or chronic [13]. In palliative care practices, it is essential to comprehensively evaluate the patient with biological, psychological and social aspects [14]. Communication skills, patient-physician relationship, educational services and interdisciplinary approach are common features used in both fields [15]. For these reasons, the involvement of family medicine specialists at every stage of palliative care service will increase the quality and quality of the service provided. There is no specialization program under the name of palliative care in Turkey [7]. There is literature that advocates the view that family physicians do not need a separate palliative care specialty on the grounds that they are quite suitable in providing adequate and necessary health care in this area [16]. In a study conducted in the Netherlands, it was shown that physicians who received training after 1 year of palliative care training for general practitioners became more sensitive in the definition of palliative care and provided multidimensional care compared to those who did not receive training [17]. Palliative care can be brought to the agenda as a subspecialty for family medicine specialists.

It has been determined that family physicians do not have sufficient training and equipment regarding palliative care in the current system. In order for palliative care services to continue in an effective and sustainable way, family physicians should work together and in communication with home care services, 2nd and 3rd level health centers. Parallel to the ever-increasing need for palliative care in primary care, some up-to-date regulations and in-service training should be brought to the agenda. If family physicians are included in the system appropriately, unnecessary hospital admissions will be reduced as they can support patients and their relatives in coping with current symptoms and anxiety related to the disease. It can be planned to support the existing units in areas such as personnel, medical equipment, reducing the workload, reducing the number of registered patients, and positively reorganizing the palliative care services in pricing in a way that will increase the motivation and desire to work in this field.

\section{Limitations}

The limitations of our study are that it was conducted in a single province and that the entire target group could not be reached for various reasons.

\section{Conclusions}

In our study, it was observed that there was a difference between family physicians' palliative care clinical practices. The most important reason for these differences is the lack of a standard training procedure on the subject. Due to the importance of the subject and the increasing number of patients in need of palliative care, more and more comprehensive studies are needed.

Conflict of interest: The authors declared no potential conflicts of interest with respect to the research, authorship, and/or publication of this article.

\begin{tabular}{|l|r|l|}
\hline \multicolumn{2}{|c|}{ Author Contributions } & \multicolumn{1}{c|}{ Author Initials } \\
\hline SCD & Study Conception and Design & UU, OS, NYC \\
\hline AD & Acquisition of Data & UU, OS \\
\hline AID & Analysis and Interpretation of Data & UU, OS, NYC \\
\hline DM & Drafting of Manuscript & UU \\
\hline CR & Critical Revision & NYC \\
\hline
\end{tabular}

Financial support: None

Prior publication: The study has not been presented at any meeting before and was not published in any journal.

\section{References}

1. http://www.who.int/cancer/palliative/definition/en/ (Accessed 01 March 2022)

2. Aydogan F, Uygun K. [Palliative treatments in Cancer Patients] (in Turkish). Klinik Gelişim. 2011; 24: 4-9.

3. Kabalak AA. Palliative care studies in Turkey. Turkiye Klinikleri J Anest Reanim-Special Topics. 2017;10(1):7-12.

4. Ozgul N, Gultekin M, Koc O, Goksel F, Bayraktar G, Ekinci H et al. Turkish community-based palliative care model: a unique design. Annals of Oncology.2012; 23 (3): 76-8. https://doi.org/10.1093/annonc/mds093

5. https://khgmozellikli.saglik.gov.tr/svg/palyatif.php (Accessed 01 March 2022)

6. Miniksar OH, Korkmaz Disli Z, Tunc Z, Acun Delen L, Honca M. Determination of knowledge and opinions on palliative care of workers in intensive care and palliative care units: a survey study J Tradit Complem Med. 2020;3(1):61-8. https://doi.org/10.5336/jtracom.2019$\underline{72380}$

7. Yildizer OF, Ogur S. Knowledge and attitudes of health personnel on palliative care: sample of Bitlis province. J Curr Res Health Sector. 2018; 8 (2), 411-38.

8. Bag B. [Palliative care practices in the health system in the case of Germany] (in Turkish). Turk J Oncol. $2012 ; 27$ (3): 142-9. https://doi.org/10.5505/tjoncol.2012.687

9. Tanriverdi O, Yavuzsen T, Akman T, Senler FC, Taskoylu BY, Turhal S et al. The Perspective of non-oncologist physicians on patients with metastatic cancer and palliative care (ALONE Study): a study of the palliative care working committee of the Turkish oncology group (TOG). J Canc Educ 2015; 30:253-9. https://doi.org/10.1007/s13187-015-0794-3 
10. Pelayo M, Cebrian D, Areosa A, Agra Y, Izquierdo JV, Buendia F. Effects of online palliative care training on knowledge, attitude and satisfaction of primary care physicians. BMC Fam Pract.2011; 12:37-47. https://doi.org/10.1186/1471-2296-12-37

11. Demir M. Palliative care ethics: Turk J Med Surg Intens Care Med.2016; 7: 62-6. https://doi.org/10.5152/dcbybd.2016.1202

12. Uyar M, Cetingok H, Ozyalcin SN. Chronic pain and access to treatment at the end of life. Comm Physician. 2016; 31(1): 18-24.

13. Benli AR, Erbesler ZA. Differences on comprehension and practice in palliative care in Turkey. Turk J Fam Pract 2016 ; 20 (1): 5-6. https://doi.org/10.15511/tahd.15.21605

14. Celtek NY, Okan I. [Patient evaluation and scales in palliative care] (in Turkish). Clin Med J Fam Med. 2016; 8(3): 6-11.

15. Dirimen Arikan G. Definition and philosophy of palliative care. Clin Med J Fam Med. 2016; 8(3):1-5.

16. Vinay P. Rebuttal: should palliative care be a specialty?: no. Can Fam Physician. 2008 ;54(7):974-7.

17. Thoonsen B, Gerritzen SHM, Vissers KCP, et al. Training general practitioners contributes to the identification of palliative patients and to multidimensional care provision: secondary outcomes of an RCT. BMJ Support Palliat Care. 2019;9(1):e18. https://doi.org/10.1136/bmjspcare-2015-001031 